\title{
THE CONTRIBUTION OF A PAINTER TO THE FULFILLMENT OF A COMMUNITY
}

\author{
Dragoş Ioan ŞUŞMAN*
}

\begin{abstract}
Sava Henția is considered one of the great painters of the 19th century, the creator of a valuable work that enriched the cultural heritage of our country. The present study intends to rediscover, based on documents from archives, an episode from his artistic career: the circumstances which led him to paint several icons for the Răhău parish church, Alba County. The episode is emblematic for the painter's nationwide renown: although he had been living in Bucharest for several decades, Sava Henția was still remembered and appreciated by the local community in Transylvania.
\end{abstract}

Keywords: painter, icon, archive, document.

\section{Who was Sava Hentia ?}

The painter and graphic artist Sava Henția was born on the $1^{\text {st }}$ of February 1848 in Sebesel ${ }^{1}$ village. He was the fifth son in the family of a priest - Ilie Henția and Ana (born Dăncilă) ${ }^{2}$. His childhood was marked by hardships and poverty since he belonged to a large family (14 children), also, the fact that the country was under foreign rule, offered him little chance for personal development. He first attended school in his home village, then in Sebeș at the German Secondary School.

* PhD, Lecturer, Faculty of Orthodox Theology at "1 Decembrie 1918” University, Alba Iulia.

${ }^{1}$ Village situated on the middle course of the Sebes Valley (Romania).

${ }^{2}$ Nicolae Afrapt places the date of birth on $1^{\text {st }}$ January. See Nicolae AFRAPT, Sebeșel Satul de pe Valea Sebeșului (Sebesel - the village on the Sebes Valley), Alba Iulia, Altip Publishing House, 2009, p. 327. 


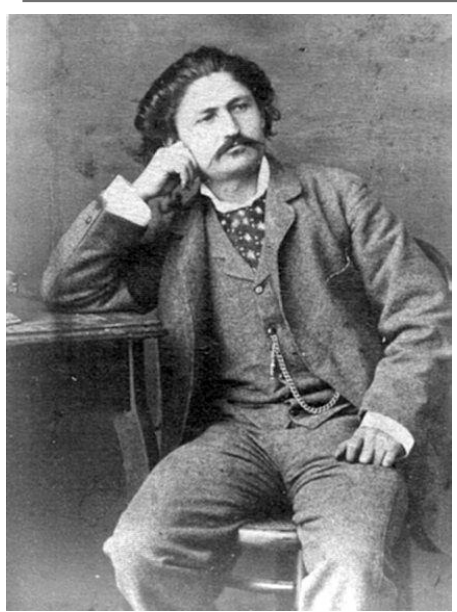

Fig.1: Sava Hentia

Quite early in his youth he gained local recognition for his religious paintings on glass, this art being well developed along the Sebeș Valley. His early success motivated him to follow a different path than his brothers, who all became priests ${ }^{3}$. In 1862, at the age of 14, he left for Bucharest, moving with his uncle on his mother's side, the photographer Zaharie Dăncilă (Dănciulescu) $)^{4}$, for whom he helped touch up photos. A year later, he became seriously ill $^{5}$ and, due to an inadequate treatment with a quinine overdose, he remained deaf for the rest of his life ${ }^{6}$. Between 1865 and 1870, he attended the courses of the Bucharest School of Art, studying painting and following the great tradition established by the founders of the school Teodor Aman and Gheorghe Tattarescu 7 .

Between 1870 and 1873, he continued his studies in Italy and

${ }^{3}$ Ibidem. The biblographic sourced do not mention how many brothers and sisters the artist had.

4 Zaharie Dăncilă, brother to Sava Hentia's mother, was the son of the priest from Răchita (the village is closely situated to Sebeșel). Cf. Ibidem.

${ }^{5}$ Some sources believe that he had typhoid fever, according to Iulia Ramona DAN, Noi contribuții la cunoașterea vieții și activităţii pictorului Sava Henţia (1848-1904) (New contributions to the life and work of painter Sava Hentia), în „Anuarul Sargetia”, p. 699 (on-line: http://www.anuarulsargetia.ro/noi-contributii-la-cunoasterea-vietii-siactivitatii-pictorului-sava-hentia; accessed at 24.02.2017).

6 According to Muzeul Municipal „Ion Raica” Sebeș, Colecția Sava Henția Pictură/Grafică (Municipal Museum "Ion Raica”, Sava Henția collection - Picture/ Graphics), Alba Iulia, Altip Publishing House, 2004, p. 3. During the same year he nearly drowned being cought in a freshnet in Dambovita, see Ion FrunZETTI, Arta românească în secolul XIX (Romanian Art in the $19^{\text {th }}$ Century), București, Meridiane Publishing House, 1991, p. 354.

7 One of his professors was Bogdan Petriceicu Hașdeu, his course was entitled Istoria românilor în raport cu pictura (|History of Romanians and its influence on painting). Cf. Nicolae AFRAPT, op. cit., p. 328. 
ARS LITURGICA. From the Image of Glory to the Images of the Idols of Modernity

France $^{8}$. At the end of 1873, after his return home, he married Irma Tanko from Petrești ${ }^{9}$, with whom he had 6 children. In order to provide for his family, he combined his artistic career with teaching. From 1875 until the end of his life, he taught drawing and calligraphy at a number of institutions: "Doamna Elena" Asylum, the Secondary School for Girls and two Pensions 'Pompilian' and 'Negoescu' 10 .

Early in his artistic career, he embraced religious and historical subjects. Inspired by the great events and personalities of the past, Hentia started painting the "portraits of all voievods and all important monuments in the history of the nation". He particularly enjoyed the Dacian - Roman period ("The Sacrifice of Trajan at Drobeta bridge over the Danube", "The Conquest of Sarmizegetusa" (1870), "The Triumphant Entrance of Emperor Trajan in Sarmizegetusa" $\left.{ }^{11}\right)$. From medieval history, he was particularly interested in the personalities and deeds of Michael the Brave and Steven the Great.

In the year 1877, (during the Romanian War of Independence), at General Carol Davilla's request (General Inspector of the Sanitary Section of the Army Head Quarters), Sava Hentia was included in the group of painters sent to the front as "war correspondents with a brush" 12 . The special conditions of work and the contact with the bitter

${ }^{8}$ It seems that he had won a scholarship with the mythological painting „Orfeu și Euridice” (lost today). He renews his scholarship at the Art Academy in Paris (between 1871 and 1873 ) with another mythological work „Psyche părăsită de Amor” - according to Sava Hentia collection, p. 3. From the information listed above we can conclude that Sava Henția stayed approx. 1 year in Italy (1870-1871) and 2 years in France (1871-1873). Nicolae Afrapt provides the information that his professors were Alexandre Cabanel and Pierre Paul Prud' hon (op. cit., p. 328). In Cabanel's case the information is plausible (he did teach in Paris between 1864 and 1889- the year of his death), on the contrary Pierre Prud hon had died in 1823 so he could not have been Sava Henția's teacher.

${ }^{9}$ Irma was the daughter of the Hungarian count Potoscky, according to Nicolae AFRAPT, op. cit., p. 328.

${ }^{10}$ Colecția Sava Henția, p. 3.

11 Mural at Căldărușani Monastery, painted after a previous sketch. Sarmisegetuza can be seen burning in the background, while, in the foreground, Emperor Trajan enters triumphantly surrounded by Legioneers. According to Nicolae AFRAPT, op. cit., p. 329.

12 Doctor Carol Davilla gave him the following recommendation: "Mr Hintzea Savu, drawing teacher at "Doamna Elena" Asylum, the Secondary School for Girls in Bucharest, is attached to the ambulance of the General Headquarter for the duration of the entire war. [...] All the people who meet Mr. Hintzea should know that he 
realities of war changed his artistic point of view. The artist was forced to access new ways of expression based on quick sketches, as opposed to elaborate paintings that took a long time to complete.

His works, mostly drawings and sketches, cover the whole war period, from the beginning of the hostilities until the triumphant return of the troops home ${ }^{13}$. After this stage, we notice a wider diversity of topics: landscapes, mundane scenes, still lifes but also portraits, which remain the dominant subject. ${ }^{14}$

For his activity, he was rewarded with diplomas, silver and bronze medals. At the Romanian Exhibition in Sibiu (1881), he received 27 prizes for his "pencil drawings, water colours and oil paintings". The diversity of his interests is evident from his collaboration in book illustration, interior decorations (Vernescu House and the ceiling of the National Theatre ${ }^{15}$ ), the murals from the churches in Vintu de Jos, Brebu and Sebes. He also painted the iconostasis of the churches in Vințu de Jos and Răhău and several icons for the churches in Sebeșel and Săsciori.

Sava Hentia died on the 21 of February 1904, at the age of $56^{16}$. Out of 238 known works of his, 44 are exhibited in the "Ion Raica" Museum in Sebeș.

\section{The Contribution of the painter Sava Hentia to the adornment of the Rahau parish church.}

The document base of the Orthodox parish church in Rahau, part of the Alba County Service of the National Archives of Romania, keeps

suffers from almost complete loss of hearing and finds it a bit difficult to interact with other people". Apud. IbIDEM, p. 330. The group of artists sent to the front also included Nicolae Grigorescu, C. D. Mirea și C. Popp de Szathmary. According to Vârstele oraşului. Sebeş - 750 de ani de atestare documentară (1245-1995) (The ages of the town. Sebes - 750 years since its first mention in documents), Sebeş, 1995, p. 132.

13 At the end of the 1877 war, most of the paintings from this military campaign were bought for Prince Charles I's private collection and the artist received the Bene Merenti Medal class II. According to Ion FRUNZETTI, op. cit., p. 365.

${ }^{14}$ IbIDEM, p. 4

${ }^{15}$ Which was distroyed during WWII

${ }^{16}$ His death is briefly announced in two newspapers: România Muzicală and Bucarester Tageblat. According to Colecția Sava Henția (Sava Hentia Collection), p. 4. 
several letters that Sava Henţia exchanged with the priest Nicolae Cărpinișan. We are now going to present the correspondence in chronological order.

The first reference to Sava Henția appears in the minutes of the Răhău Parish Committee meeting on the $11^{\text {th }} / 23^{\text {rd }}$ August $1896^{17}$. The object of the meeting was to decide on the painting of four imperial icons for the iconostasis of the church, an old wish of the committee members. In order to fulfill this wish, the committee urged Fr. Nicolae Cărpinișan to get in touch with Simeon Hința ${ }^{18}$ in Bucharest to ask him to paint the icons. The artist responded, writing a letter to the priest, mentioning that he would make "four large icons and four small ones, according to the annexed model for the sum of 240 florins." 19 Furthermore, since the painter was spending the summer holiday at his relatives in Sebeșe ${ }^{20}$, on the $3^{\text {rd }}$ August, at the request of the parish committee members "he came in person to the church, contemplated the place and took the measurements for the icons. In accordance with the shape, size and type of execution, he now demands 620 lei, the equivalent of 279 florins. The committee has to meet again to discuss the matter" 21 . The committee appreciated the gesture of the painter to come in person in order to get precise information, and decided to order "4 large icons: Lord Jesus Christ, sitting on a throne, dressed as a bishop and wearing a crown, The Mother of God sitting on the throne as Eternal Empress wearing a crown, the icon of St. George standing with the defeated dragon under his feet, (but without a horse), and the icon of St. John the Baptist, standing. For each one of these icons, a small version must be also painted. The panel must be of populous wood and

${ }^{17}$ Romanian National Archives, Alba County Branch, the fund of the Răhău Orthodox Parish, sheets 19 v. și 20.

18 We do not know the reason why the first name of the artist appears to be Simeon instead of Sava in this document. In our opinion, the situation could have two possible explanations: either the members of the committee didn't know his name for sure, or it was just a mistake of the person who kept the minutes. The first explanation is less plausible, since Sava Henția had already sent a letter to the Răhău parish office, he had also signed the letter.

${ }^{19}$ Ibidem, sheet $19 \mathrm{v}$.

20 Sava Henția used to visit his birthplace every summer alone, since his wife didn't want to accompany him, according to Nicolae AFRAPT, op. cit., p. 328.

${ }^{21}$ The Răhău Orthodox Parish, sheets 19 v. and 20. 
the frames must be covered in gold leaf. The icons will be sent after completion and the committee will offer $240 \mathrm{fl}$, the sum will be collected from parishioners during the autumn of 1896 and from the treasury of the church". ${ }^{22}$

The decision was given to the artist by a parish delegation to Sebeșel, within a few weeks, before his return to Bucharest.

During this meeting, in the presence of Sava Henția's brother, Nicolae, the parties settled the price, the deadline being announced later on by post. This is why on the $16^{\text {th }}$ October 1896 , the artist sent a letter from Bucharest, telling the priest from Rahau that "the big icons are ready except the gilding of the frames, consequently I'd like to inform you that the deadline was set to November, and I did my best to comply"23. The painter asked for further details about the way the icons should be packed and posted, and the way in which the money would arrive to him: "we will have to agree on how you want the icons to be sent and where, in the village or in Sebes. As for the method of payment, will you send the money before or after receiving the icons?". He recommended "unpacking at Sas-Sebeș in the presence of the of His Reverence the Protopope to attest that the icons of the Mother of God and Jesus Christ look like the ones in the church at Sebeș". ${ }^{24}$

On the $5^{\text {th }}$ November 1896, Sava Hentia sent another letter to Fr Cărpinișan, asking for forgiveness for not replying sooner, but "to this date" he was not able to finish gilding the frames. After promising to finish them by the $10^{\text {th }}$ of December, he added: "Please send me 100 florins as soon as possible, as for the rest, I can wait a little more. This money is very useful for presents, because I wouldn't like to send them in two rows. I have sent you all the 8 icons at once, to avoid spending double and wasting time, since I am very busy." 25

On the $27^{\text {th }}$ November/ $9^{\text {th }}$ December $1896^{26}$, the ledger of income and expenditure of the Rahau parish church attests that 103 florins and 45 krajczárs had been taken from Sebeșana Bank and 101 florins had

22 Ibidem, sheet 20.

${ }^{23}$ IDEM, file 109/1896, sheet 1.

${ }^{24}$ Ibidem, sheet $1 \mathrm{v}$..

${ }^{25}$ IDEM, file 108/1896, sheet 1 (see Fig. 6).

26 The order of events forces us to take into consideration the dates in the new (Gregorian) calendar in accordance with the dates on Sava Hentia's letters. 
ARS LITURGICA. From the Image of Glory to the Images of the Idols of Modernity been already sent "to Mr Henția in Bucarest for the icons"27. On the same day, the artist sent the parcel with the oil paintings by coach, according to the postal letter. ${ }^{28}$

On the $28^{\text {th }}$ November, Sava Hentia informed the priest that "the trunk with the icons inside have already arrived at the Alvirez railway station, because the post cannot carry a load bigger than $10 \mathrm{~kg}$, your reverence will have to go to the station and collect the trunk. We have already paid for the transport to the Predeal border; your reverence will have to pay for the transport on the Hungarian territory, because the authorities wouldn't allow us to pay for the whole trip, it seems you will pay for the customs as well. Apart from the icons, the trunk contains two portraits of the Tipeiu protopope: so it is necessary to open the trunk at Sas Sebeș as well." ${ }^{29}$ At the end of the letter, the painter adds a personal request: "please show the icons to more people in Sas-Sebeș, especially the ones that I have contacted before. [...] And if other churches need icons, let us know beforehand, so we may have plenty of work there next summer. Please invite other priests to come and see the icons as well." ${ }^{30}$

On the $16^{\text {th }}$ December, Sava Hentia sent a worried message to Fr. Cărpinișan: “I don't understand why you haven't replied yet to the letter

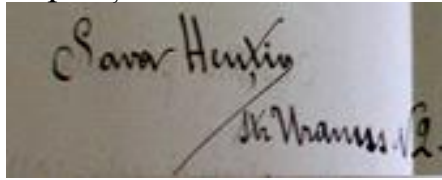

Fig. 2: Sava Hentia's signiture I sent with the icons! Maybe you haven't received them, which I doubt. I sent the icons with great speed ${ }^{31}$ and they are, in any case, at Alvinez station. Please, send a reply, because we are a little worried. I sent the icons three weeks ago". ${ }^{32}$

On January $1^{\text {st }} 1897$, Sava Henția sent the message marking the end of the transaction between him and the Răhău parish: "Today at 12,

${ }^{27}$ IDEM, file 326, sheet 13 v.. Probably the difference of 2,45 florins between the sum taken and the one sent to the painter covered the dispatch costs.

${ }^{28}$ IDEM, file 110/1896, sheet 1 (see Fig. 3).

${ }^{29}$ IDEM, file 107/1896, sheet 1 (see Fig. 4).

${ }^{30}$ IDEM, sheet 1v (see Fig. 5).

${ }^{31}$ Indeed, the postal letter mentions ,great speed" on the envelope.

32 IDEM, file 106/1896, sheet 1 (see Fig. 7). This statement is rather puzzling since between 9th December (the date mentioned on the postal letter) and 16th December (the date in which his letter was sent) there are only 7 days (a week). Probably the 2 weeks difference was given by the calendars used (Gregorian vs. Julian). 
I happily received the postal order with the payment for the icons (...) consequently, I am most grateful and I congratulate your reverence and the entire parish committee from Răhău. It would be nice if other villages followed your example. I would be extremely happy to work again among Transylvanian brothers" ${ }^{33}$.

\section{Conclusions:}

The correspondence between Sava Henția and Fr. Nicolae Cărpinișan from Răhău shows the fact that the bond between Romanians were not torn by geographical borders. Moreover, the letters offer a more comprehensive image of the man behind the artist: a Transylvanian who is respectful and warm in conversation, a man who in spite of reaching great heights in recognition of his art, is not condescending towards his brothers, but on the contrary, is pleased to be of help. Being part of the era in which cultural exchanges between Transylvania and Romania intensified, we can honestly say that Sava Henția contributed to the crystallization of Romanian national conscience.

\section{References:}

1. Romanian National Archives, Alba County Branch, the fund of the Răhău Orthodox Parish.

2. AFRAPT, Nicolae, Sebesel - the village on the Sebes Valley, Alba Iulia, Altip Publishing House, 2009.

3. DAN, Iulia Ramona, "New contributions to the life and work of painter Sava Hentia (1848-1904)", in Anuarul Sargetia (on-line: http://www.anuarulsargetia.ro/noi-contributii-la-cunoasterea-vietii-siactivitatii-pictorului-sava-hentia (accessed at 24.02.2017)

4. FrunzetTI, Ion, Romanian Art in the $19^{\text {th }}$ Century, București, Meridiane Publishing House, 1991.

5. *** Municipal Museum "Ion Raica", Sava Henția collection - Picture/ Graphics, Alba Iulia, Altip Publishing House, 2004.

6. *** The ages of the town. Sebes - 750 years since its first mention in documents (1245-1995), Sebeş, 1995.

${ }^{33}$ IDEM, file 105/1896, sheet 1 (see Fig. 8). We mention the fact that this letter is the only one the painter signed with the title ,,professor". 


\section{ANNEXES}

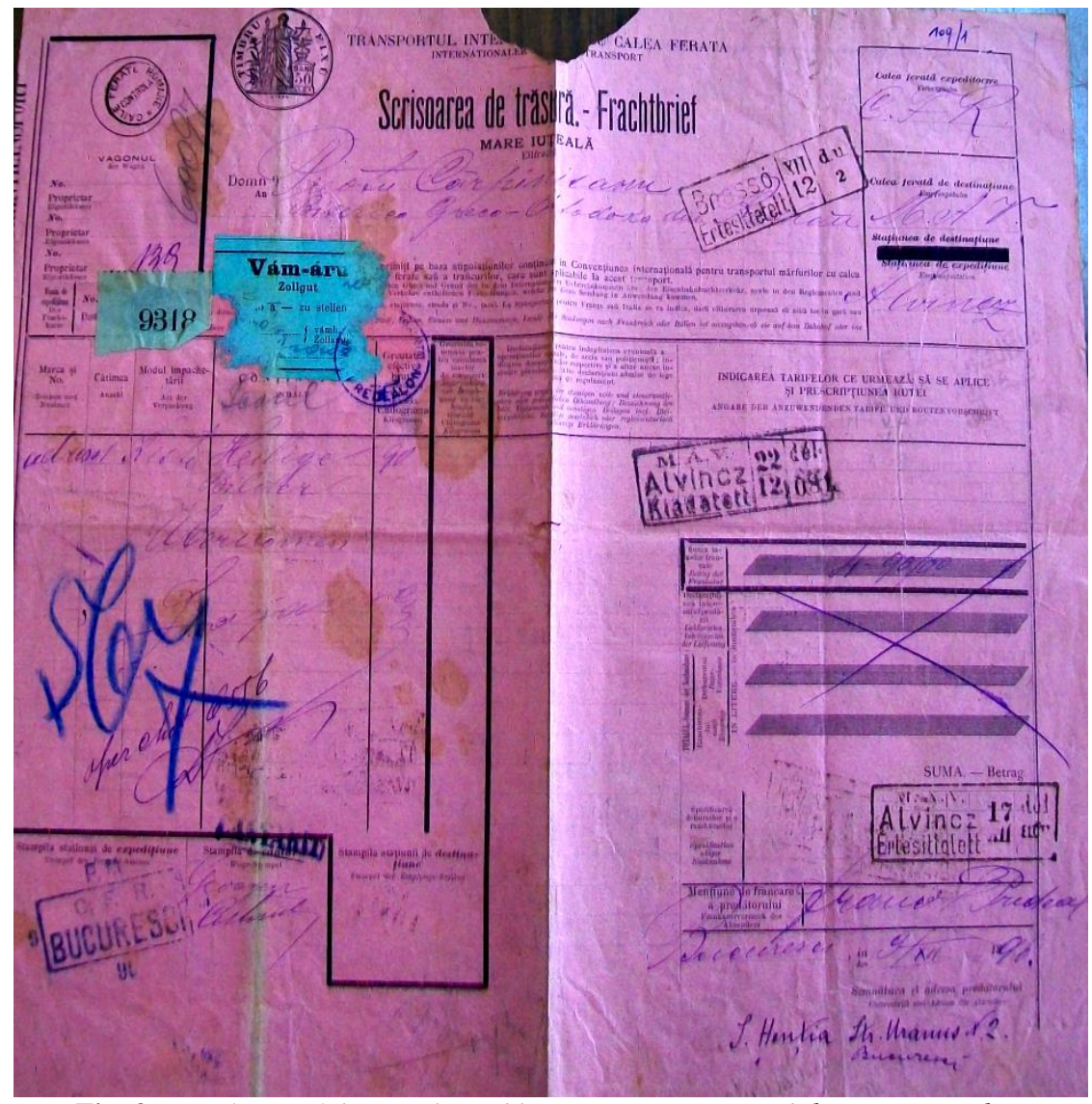

Fig. 3: Post letter of the coach used by Sava Hentia to send the icons to Răhău 
$16^{\text {th }}$ International Symposium on Science, Theology and Arts (ISSTA 2017)

406 28 Noentiric Osucuresce.1

Cncernices pörinter.

Pà fac cumosent cum éa lada en ieonele sunt sosite in garon Clvinez; fünolca postar mu gioter bransporta grentati mou mulx de 10 chilograune ofintia voskiór sunte ti nevoiti a vé duce la gará sà seoteli lavola. - Transportul jâría la gramita Iredeal an platat noi; iar pe Xeritorin Ungar sunketi neviiti if vóstrá a plöti de orece moné mì me a primit a plati páná lo, locul de olestinatie; ini prore cá o sá plálití ceva rama. In ladà se allà si doué fortucte

Fig. 4: Sava Hentia's letter on 28.11.1896 (p. 1)

214 
ARS LITURGICA. From the Image of Glory to the Images of the Idols of Modernity

de protopopului Sipein ; deacea trebue ea só desfoća i lada sila Sas-Sebes; tot de odata sà aroutartú si iconcle ca sà le vadou mori. mulxidin Sas-Sebes, pe acei celeom 'fäcut cunoscuito sá vip sàle vado - -

Cred cir o se vè flaco iconelpisi docè or mor 'Krebri si jentru âlle Biserice ve rog só me fòce ti cmosent ca la vorró sor avem de lincru pe

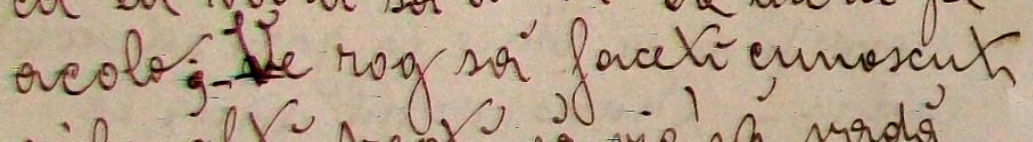
sila alli Areo-ì sa vie'sa madà iconele - I

In sferanta Af. vistre remón ol invostre devotax-fictor. foura Hentir Ju. Wromus of 2.

Fig. 5: Sava Hentia's letter on 28.11.1896 (p. 2)

215 
$16^{\text {th }}$ International Symposium on Science, Theology and Arts (ISSTA 2017)

Sonurest 5 wo combinin 1896.

Comirate Sarinte

Di rague a auda Jo mu vam raspunsur

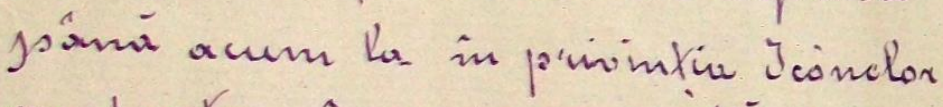
counda esta ca inca nici pana istá di musom pritutirtermina en auritul ramulorin. Toem. - air la 10. Nombrie suntur yatus. catur punter es an ati acris in privinta platir

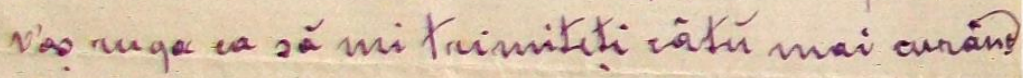

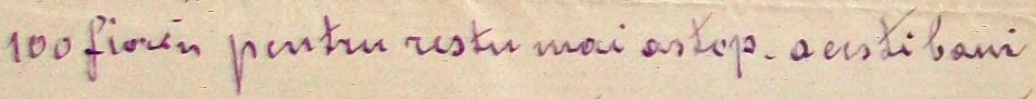
suntue ca usuraic punteu radouri. mons convina Se locur a lu trumite in Soniz rônduri Eu vile trimitü pe tote 8. de ore ee säfañ chatrud Suble, si perdere Se timpir. firins forta our patiu. Soci in grabá ea cannele vocue i gata, vile,osprosal.

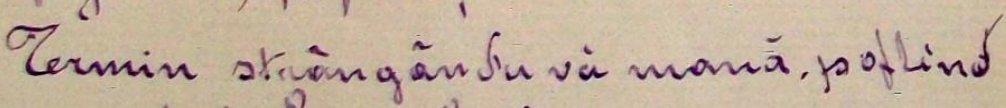
sanatate families.

Sava Fientio

Fig. 6: Sava Hentia's letter on 05.12.1896

216 


$$
\text { S nemera } 1
$$

Cnorater porrinter

Nur stinir ce ester consor der mu nue moir rispunde ti lor scrisorea ee v'anr times'or o doxior eur icomeler! - Síte cor sur le or- $X_{i}^{2}$ primit, cear ce mu cred. Deonde le anw Ximis en more vitesia;-siv suntin Xol casul la garar 'Alvinez. Fer rog respundeti lov acestió scrisores, fundeor suntenr conn ingriforalir. T) concles sunt Xir-r miser der'Xreir septemanir.-

Fig. 7: Sava Hentia's letter from 16.12.1896 
$16^{\text {th }}$ International Symposium on Science, Theology and Arts (ISSTA 2017)

Bunmesti 1. Jamnonie 1897.

$10 Y$

Oriverte Sorinte

Ostá di la ora 12. am avutu firicura a pommi mandakut en plata Teioneloris en en in conorderatio areasta ca, ná idvia sublina Sfli. nootro. pentru care ma grabesew a va trimite caldurosite mele mult, =

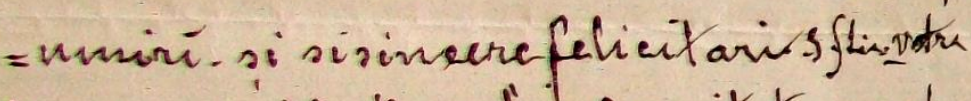

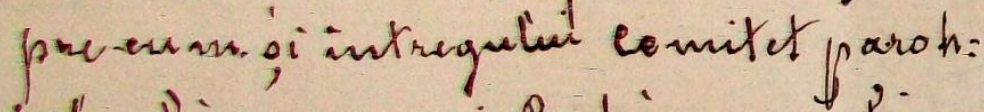

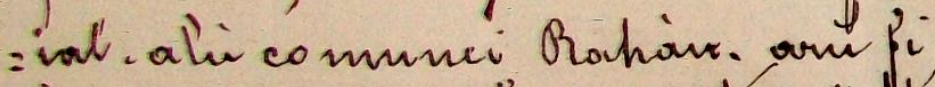
Prumosin davea avir. in mita si alle commer exemplul, Datión en din partem. m.ap simti cel mai for citriathera in triár f'raxti transitua: nieni.. Salution si stran operi de

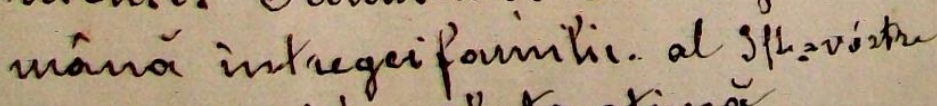
en eca maidcosabla stimä. Srotesom Yava Hentior Mroms. 2 .

Fig. 8: Sava Hentia's letter from 01.01.1897

218 